\title{
Application of electrical resistivity test to estimate carbon storage of tropical peat deposit (Case study of Bengkalis island)
}

\author{
Muhammad Yusa $^{1, *}$, Ari Sandyavitri ${ }^{1}$, and Sigit Sutikno ${ }^{1}$ \\ ${ }^{1}$ Department of Civil Engineering, Universitas Riau, Pekanbaru, Indonesia
}

\begin{abstract}
Indonesia has approximately 21 million hectares (ha) of tropical peat land, equivalent to $80 \%$ of peat deposit in Southeast Asia. It was estimated that Indonesia has 1.5 Giga tonne of carbon stock. However the estimation is still rough because there was no calculation of volume yet. This study explain the use the geophysical method of electrical resistivity test (ERT) combined with real time kinematic (RTK) and laboratory test to estimate the volume of peat deposit. Direct boring was also done to verify the ERT results. The location of study is in Bengkalis Island, Riau-Indonesia. Twelve (12) locations of ERT has been conducted covering area of 127164.667 ha. Visual observation from boring sample reveal that the peat in generally are fibric to hemic or H2-H6 according to Von Post classification. The peat layer has resistivity value range between 20-150 ohm meter. In general the peat can be classified as very deep peat with average thickness of $6.4 \mathrm{~m}$. The ERT revealed that average lateral variability of peat thickness electrode line is less than $0.6 \mathrm{~m}$. The estimated peat volume is $6803206275.152 \mathrm{~m}^{3}$. The average ash content is $6.5 \%$ which equivalent to $53.9 \%$ of carbon content. The average bulk density is 0.09 tonne $/ \mathrm{m}^{3}$. It was estimated the carbon sink of the location is 330023536.41 tonnes which equivalent to 2595.3 tonne/ha.
\end{abstract}

\section{Introduction}

It is well established that peatland has a very strategic function as a hydrological unit, carbon storage, and biodiversity. Despite only cover little 2-3\% of earth land, peatland can peatland contain up to $30 \%$ of the global soil carbon [1]. Furthermore, tropical peatland, $11 \%$ of global peatland, was estimated to store more than $30 \%$ of the global peatland carbon or about 50 [2] to $105[3,4]$ Gigatons of carbon. Degradation of tropical peatland releases greenhouse gases with a significant effect on global environmental change processes. Huijnen [5] reported that Indonesia peatland fire in September to October 2015 results in $11.3 \mathrm{Tg} /$ day of $\mathrm{CO}_{2}$ emission which exceeded the fossil fuel $\mathrm{CO}_{2}$ release rate of the European Union, i.e., $8.9 \mathrm{Tg} /$ day. Also, the total current $\mathrm{CO}_{2}$ emission from degraded peat area equal almost $8 \%$ of global emission from fossil fuel burning [6].

\footnotetext{
*Corresponding author: m.yusa@eng.unri.ac.id
} 
On the other side, Indonesia is one of the country in the world which has a large area of peat, i.e., 20.6 million hectares or about $11 \%$ of its land area. The area covers almost 38\% of world tropical peatland and $80 \%$ of Southeast Asia peatland [7]. However, in term of the volume, the estimation is still very rough because of limited data of peat thickness. Existing Indonesia's peat map has 1:250000 scale [8], with very rough peat thickness estimation, based only two categories, i.e., shallow $(<3 \mathrm{~m})$ and deep $(\geqq 3 \mathrm{~m})$ peat. This, in turn, results in a very rough estimate of carbon sink of Indonesia peatland.

Conventional peat volume estimation utilizes 'gridding system' of visual inspection of peat boring sample. Agus et al. [9] reported that the variation of peat thickness in $50 \mathrm{~m}$ could range 10-50 cm which implies grid spacing less than $50 \mathrm{~m}$. The method is deemed reliable to identify peat depth but labor and time-consuming. Considering the wide area of Indonesia's peatland, the method will require much time and cost. This study attempted to utilize a combination of the geophysical method using electrical resistivity test (ERT), global stationing position (GPS) geodetic and peat boring. It is expected that the method will minimize the number of direct boring hence faster results, relatively cost-effective.

\section{Methodology}

\subsection{Location}

The location of this study is in Bengkalis Island, Riau Province-Indonesia. Bengkalis is an island which located at the eastern coast of Sumatra Island, i.e., $1^{\circ} 30^{\prime} 0^{\prime \prime} \mathrm{N}$ and $102^{\circ} 15^{\prime} 0^{\prime \prime} \mathrm{E}$. Figure 1 shows the location of the study. Based on the geological map, the lithology of the site is quaternary alluvial composed of clay, silt, clean gravel, vegetation raft, and peat swamp. The aquifer can be classified as moderate to low transmissivity, depth to water table varies and well generally yield less than 5 liters/sec[10].

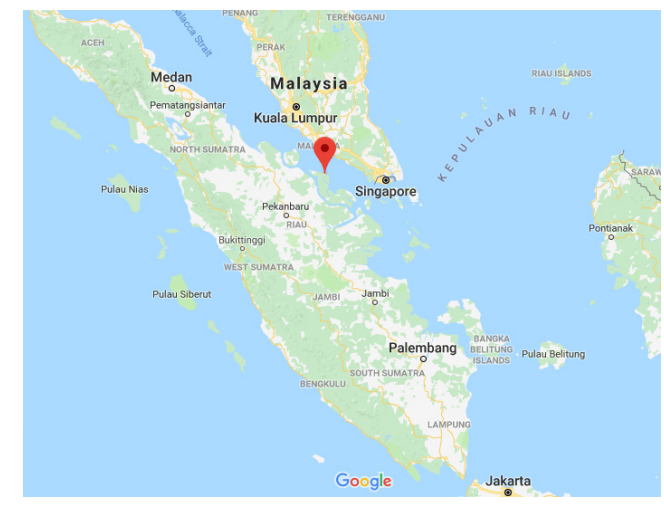

Fig. 1. Location of study.

\subsection{Equipment}

Basically there are three equipment used in this study. They are GPS geodetic, peat sampler and ERT. Detail each equipment is described in the following subsection.

\subsubsection{Electrical Resistivity Test (ERT)}

ERT is one of a non-destructive method to investigate the sub stratigraphy profile. It uses the fact that each material has a certain range of electrical resistivity. By injecting electrical 
current into the ground, the voltage difference between electrode pairs is measured. Numerical methods are used to solve the Poisson equation relating to the theoretical voltage at the electrodes to the distribution of subsurface resistivity. After that, inverse methods are applied to match the subsurface resistivity model to measured field data. The results, i.e., resistivity structure describes the ability of the subsurface to conduct electrical current. The resistivity is very much affected by water content, the chemical composition of the water and particle size distribution.

The ERT used in this study is ARES advance multi channel automatic resistivity, manufactured by GF instrument (Fig. 2). It mainly consists of transmitter and receiver. The transmitter has power up to $850 \mathrm{~W}$, current up to $5 \mathrm{~A}$ (24 bit resolution) and 2000 voltage. Whilst the receiver has 10 channel, input voltage $\pm 20 \mathrm{~V}$ and input impedance of $20 \mathrm{M} \Omega$.

In this study, Wenner method was chosen as it had the fast time response and provided a relatively good resolution. There were 48 electrodes used with $1.5 \mathrm{~m}$ interval spacing which gave $72 \mathrm{~m}$ of path length. The configuration gave maximum depth of about $12 \mathrm{~m}$. The direction of the electrode line is north-south. The analysis and inversion process was performed using RES2DINV software developed by Loke [11].
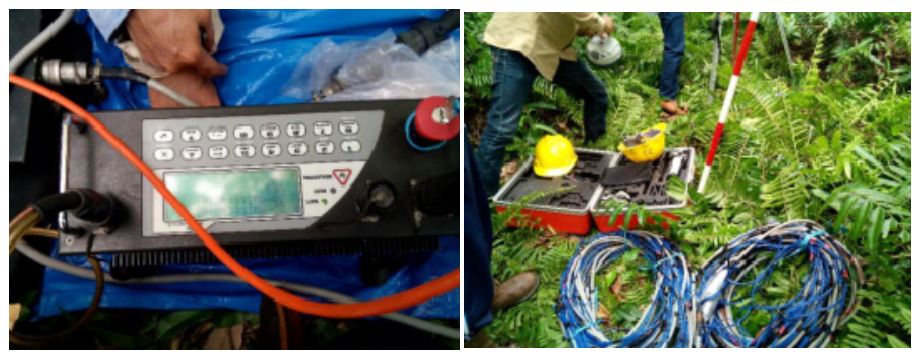

Fig. 2. ERT.

\subsubsection{Peat sampler and index properties}

In every electrode path of ERT, one point of boring was conducted at approximately 2 meters from the middle of the electrode path to validate the result of ERT. Boring was done using special hand boring, i.e., Eijkelkamp peat sampler as shown by Fig. 3. The lowest part of the equipment is half cylindrical cone which closes and contain the peat sample when the rod handle is rotated. Sample observation was conducted at interval $50 \mathrm{~cm}$. Peat layers were described in the field as peat, clayey peat and clay. Classification of peat was done according to Von Post's classification [12]. $5 \mathrm{~cm}$ of the representative sample was taken, the weight was measured directly in the field. The sample then sent to soil mechanic laboratory further tests such as ash content and bulk density.

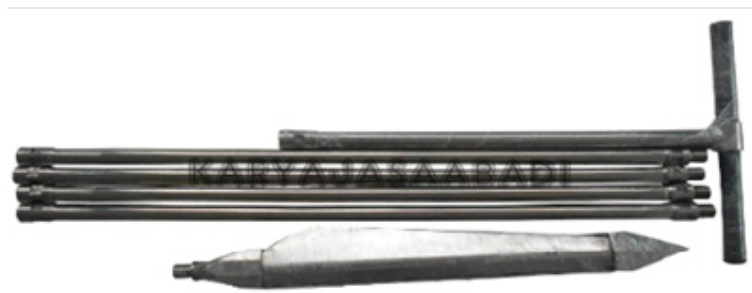

(a)Eijkelkamp peat sampler.
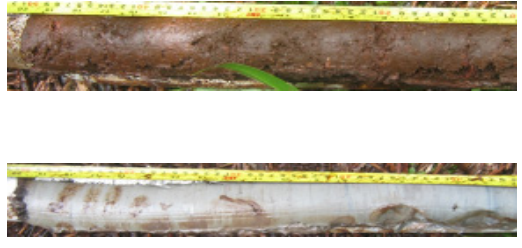

(b) Obtained samples.

Fig. 3. Peat sampler and sample. 


\subsubsection{GPS Geodetic}

The GPS geodetic is used to determine the location of the boring and ERT path. The GPS is real-time kinematic (RTK) manufactured by Sokkia and has the accuracy up to one centimeter. The equipment consists of the transmitter and receiver as shown by Fig. 4. The survey was conducted along the electrode path and ERT cable.
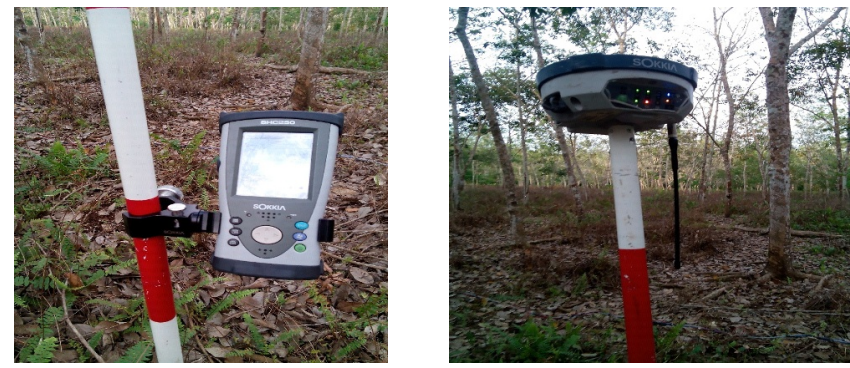

Fig. 4. Real time kinematic GPS.

\subsection{Points of investigation}

Before the field tests commenced, a literature study was done which includes the geological map, topographical map, land use map, and previous study to determine the proposed location. Also, some interview with the local people was also conducted regarding the site and estimated peat depth. In total there are twelve locations in this study. Fig. 5 shows the site of all points boring in this study. The planar area of the location is $127,164.667 \mathrm{ha}$.

\section{Results and discussion}

\subsection{General}

On average it took about 25-30 minutes to conduct the ERT along $72 \mathrm{~m}$ electrode line. On the other hand, one point of direct boring took about more than 30-60 minutes. It was not uncommon after some depth, the peat sampler hit wood trunk and cannot be penetrated further thus the location of direct boring had to be moved.

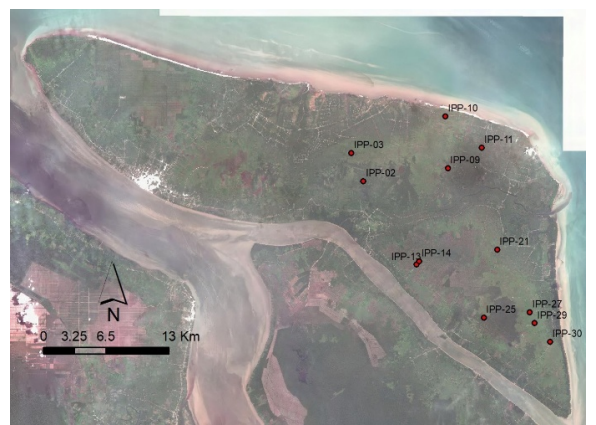

Fig. 5. Points of investigation.

Groundwater table was encountered at $5-130 \mathrm{~cm}$ from the ground surface. Boring results reveals that the thickness of peat varies from $0.5 \mathrm{~m}$ to $9.5 \mathrm{~m}$ (Table 1). Peat thickness from direct boring is shown in the $4^{\text {th }}$ column of the table. Average peat thickness ( $5^{\text {th }}$ column of the table) was calculated considering the lateral variation from the 
interpretation of ERT result, as exemplified in sub-section 3.2. Generally, the peat can be classified as very deep peat $(>3 \mathrm{~m})$ peat except for IPP-02 which is deep peat $(2-3 \mathrm{~m})$. Using the planar area the average thickness (considering lateral variability) of peat is $6.4 \mathrm{~m}$. The average lateral variation of peat thickness from direct boring is generally less than $0.6 \mathrm{~m}$. In term of peat classification, the peat in this study range from young/ fibric to intermediate (hemic) or H2-H6 according to Von Post classification.

Table 1. Peat thickness.

\begin{tabular}{|c|c|c|c|c|c|c|}
\hline \multirow{2}{*}{ ID } & \multicolumn{2}{|c|}{ Coordinate } & \multirow{2}{*}{$\begin{array}{l}\text { Thickness } \\
\text { based on } \\
\text { boring }(m)\end{array}$} & \multirow{2}{*}{\multicolumn{2}{|c|}{$\begin{array}{c}\text { Lateral depth } \\
\text { variability } \\
\text { based ERT (m) }\end{array}$}} & \multirow{2}{*}{$\begin{array}{c}\text { Average } \\
\text { thickness, based } \\
\text { on ERT and } \\
\text { boring }(\mathbf{m})\end{array}$} \\
\hline & $\mathrm{X}$ & Y & & & & \\
\hline IPP-02 & $165,535.577$ & $197,064.458$ & 2.8 & 1.6 & 3.8 & 2.7 \\
\hline IPP-03 & $165,735.980$ & $165,660.471$ & 6 & 7.3 & 8.0 & 7.1 \\
\hline IPP-09 & $164,150.266$ & $209,973.221$ & 4.4 & 4.8 & 5.4 & 4.9 \\
\hline IPP-10 & $169,612.090$ & $209,738.600$ & 6 & 7.3 & 7.3 & 6.8 \\
\hline IPP-11 & $166,333.748$ & $213,465.540$ & 4.2 & 5.9 & 5.9 & 5.4 \\
\hline IPP-13 & $154,288.763$ & $206,714.559$ & 6 & 4.8 & 5.3 & 5.4 \\
\hline IPP-14 & $154,589.046$ & $209,682.726$ & 7 & 4.8 & 5.7 & 5.8 \\
\hline IPP-21 & $155,880.317$ & $215,046.709$ & 7 & 7.3 & 6.8 & 7.1 \\
\hline IPP-25 & $147,346.7725$ & $213,151.990$ & 6.2 & 7.3 & 7.9 & 7.1 \\
\hline IPP-27 & $149,333.743$ & $218,481.465$ & 9.5 & 9.4 & 10.1 & 9.7 \\
\hline IPP-29 & $148,281.997$ & $218,947.606$ & 9 & 9.4 & 9.4 & 9.3 \\
\hline IPP-30 & $146,413.295$ & $220,475.673$ & 6 & 6.6 & 6.0 & 6.2 \\
\hline & & average & 6.2 & 6.4 & 6.8 & 6.4 \\
\hline
\end{tabular}

ERT results show that of the resistivity of peat layer range from 20-150 ohm meter. This range is consistent with the result from Comas et al. [13] which based on Borneo's peat properties. Laboratory result shows that the ash content ranges from 3.4 to 12.2 with an average of $6.5 \%$ or average organic content of $93.5 \%$. The bulk density vary from 0.08 to 0.14 tonne $/ \mathrm{m}^{3}$ which is consistent with published literature such as Walter et al. [14]

\subsection{Result example of one location}

Due to pages limitation, only one location (IPP 21) is described here as an example. The site is within a coconut farm, about 60 meters from the local road. The ground surface is dry. The groundwater level was encountered at $50 \mathrm{~cm}$ below the ground surface. Fig. 6 shows subsurface resistivity distribution along with the boring location. The figure shows one major advantage of ERT compares one discrete point of boring, i.e., that lateral ground variability can be identified along the $72 \mathrm{~m}$ electrode line. Visual observation from direct boring sample reveals that the ground profile consists of the $7 \mathrm{~m}$ thick of peat followed by a layer of clay. The peat layer can be classified as fibric (young) to hemic (intermediate) or $\mathrm{H} 2-\mathrm{H} 4$ according to Von post Classification. It can be seen from the figure that the range of resistivity values of the peat layer is $25-90 \mathrm{ohm}$ meter. Based on the range in this location, the thicknesses of the peat to the left side and right side are estimated $7.3 \mathrm{~m}$ and $6.8 \mathrm{~m}$. The figure reveals that the lateral peat thickness variability along the electrode line is less than $0.5 \mathrm{~m}$. Thus for this location, the average thickness along the $72 \mathrm{~m}$ electrode line is approximated equal to $7.03 \mathrm{~m}$. The procedure is repeated from the other's location. 


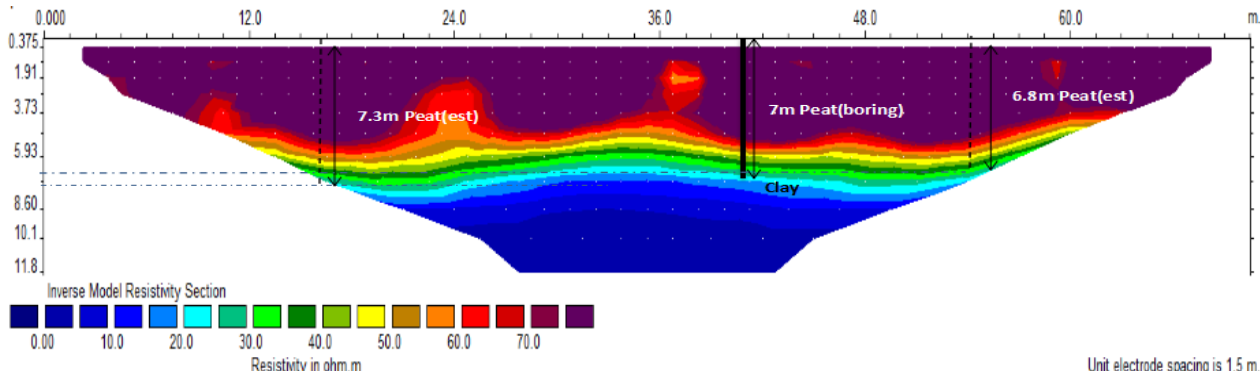

Fig. 6. Real time kinematic GPS.

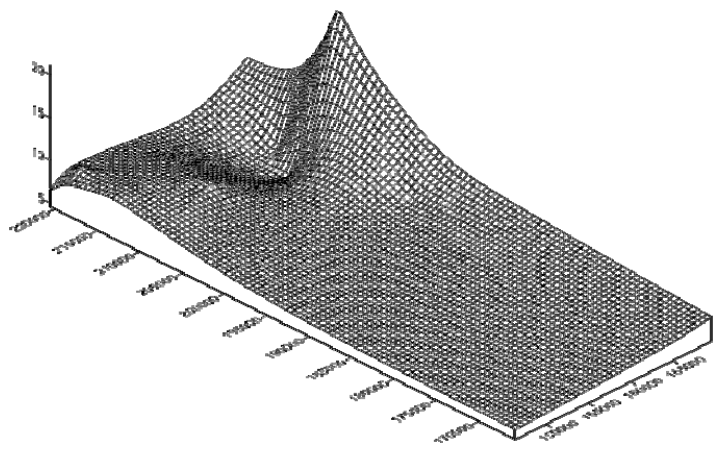

(a)

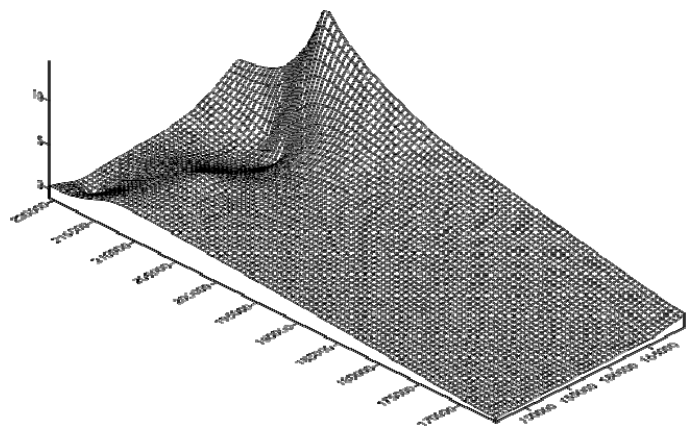

(b)

Fig. 7. Surface of (a) topography and (b) peat depth.

\subsection{Peat volume estimation}

Based on the topographical coordinates and the average peat depth from all locations, contour surfaces are drawn using topographical software. Fig. 7 (a) presents an upper surface, i.e., topographical surface and Fig. 7(b) shows peat depth surfaces. The volume between two surfaces is calculated by dividing the area of interest up into small rectangular pieces, and then the sum volume of the small three dimension rectangles between them. Utilizing the automatic tools in the software, it can be calculated that the volume between the upper and lower surface is $6,803,206,275.152 \mathrm{~m}^{3}$. 


\subsection{Estimation of carbon storage}

Carbon storage $\left(\mathrm{C}_{\mathrm{s}}\right)$ can be empirically estimated by equation below

$$
\mathrm{C}_{\mathrm{s}}=\mathrm{V} \cdot \mathrm{C}_{\mathrm{d}}
$$

where $\mathrm{V}$ is the estimated peat volume and $\mathrm{Cd}$ is the multiplication of carbon content and unit weight of peat.

The average bulk density is taken as 0.09 tonne $/ \mathrm{m}^{3}$. As the the equipment for total $\mathrm{C}$ analysis (elemental $\mathrm{CN}$ analyzer) was not available, the carbon content, $\mathrm{C}_{\mathrm{d}}$, is estimated from the results of ash content test and previous literature of organic content to carbon content ratios. The average ash content is taken as $6.5 \%$ thus average organic content is $93.5 \%$. Klingenfub et al [15] reported that for fibric to hemic peat the ratio of organic content to carbon content is $1.73-175$. Hence the carbon content is this study is $53.6-54.2 \%$. The is in the lower side of the published average $C_{d}$ values of Indonesia's peat which range $54.5-69.8 \%$ [16]. Taking $53.9 \%$ as the average, the estimated carbon stock for this study is $3,520,251,055.015$ tonnes. Using the plannar area of the location of study i.e .127164 .667 acre then the carbon sink is estimated 2595.25 tonnes/ha. This number is consistent with by Agus and Subiksa's finding[17] who reported that carbon stock range 300-700 tonne $/ \mathrm{ha} / \mathrm{m}$ peat depth I.e for average peat thickness of 6.4 the range is 1920 tonne/ha to 4480 tonne/ha.

\section{Conclusions}

Combination of ERT and direct boring can identify peat volume better because the ERT account for lateral variability in peat thickness. The method can minimize the number of boring. The range of resistivity of the peat layer in this study is between 20-150 ohm meter. Based on the thickness, the peat can be classified as very deep peat with an average depth of $6.4 \mathrm{~m}$. The estimated peat volume is $6,803,206,275.152 \mathrm{~m}^{3}$. The average ash content is $6.5 \%$ which give approximately $53.9 \%$ of carbon content. Using the average bulk density of 0.09 tonne $/ \mathrm{m}^{3}$, it was estimated the carbon sink for the location of this study is $3,520,251,055.015$ tonnes.

The authors would like to thanks the University of Riau Research Scheme (PUPT no $665 / \mathrm{UN}$.19.5.1.3/PP/2018) which has made this research possible.

\section{References}

1. D. Murdiyarso, K. Hergoulac'h, L.V. Verchot, Proc. Natl Acad. Sci. 107 (2010)

2. Z. Yu, J. Loisel, D. Brosseau, D. Beilmann, S. Hunt, Geophys. Res. Letter 37, 13 (2010)

3. S.E. Page, J.O. Rieley, C.J. Banks, Glob. Change Biol. 17 (2011)

4. J. Mietinnen, C. Shi, S.C. Liew, Glob. Change Biol. 17 (2012)

5. V. Huijnen, M. J. Wooster, J.W. Kaiser, D.L.A Gaveau, J. Flemming, M. Parrington, A. Inness, D. Murdiyarso, B. Main, M. Van Weele J. Sci. Rep. 6 (2016)

6. A. Hooijer, H. Woosten, M. Silvius, S. Page, Report R\&D Q3943/Q3684/Q4142 (2006)

7. W.S. Ritung, Suparto, H. Subagjo, Wetland International Indonesia Programme (2005) 
8. W.S. Ritung, K. Nugroho, H. Sukarman, Suparto, C. Tafakresnanto, Peta lahan gambut Indonesia skala 1:250000 (Balai Besar Litbang Sumbserdaya Lahan Pertanian, 2011)

9. F. Agus, K. Hairiah, A. Mulyani, World Agroforestry Center Southeast Asia Regional Program and Indonesian Centre for Agricultural Land Resources and Development (2011)

10. N.R. Cameron, S.A. Gazali, S.J. Thomson, Geological map sheet Bengkalis (1982)

11. M.H. Loke, Res2DInv ver 3.59.102. Instruction manual (2010)

12. L. Von Post, Das genetische system der organogenen bildungrn scheweden (1924)

13. X. Comas, N. Terry, L. Slatter, M. Warren, R. Kolka, A. Kristiyono, N. Sudiana, D. Nurjaman, T. Darusman, J. Biogeoscience 12 (2015)

14. K. Walter, A. Don, B. Tiemeyer, A. Freibauer, Soc. Sci. Am J. 80 (2016)

15. C. Klingenfub, N. Robkopf, J. Walter, C. Heller, J. Zeitzh, J. Geoderma 235-236 (2014)

16. M. Warren, K. Hergiolach, J.B. Kauffman, D. Murdiyarso, R. Kolka, J. Carbon Balance Manage 12, 12 (2017)

17. F. Agus, I.G.M. Subiksa, Measuring carbon stock in peat soils (Balai Penelitian Tanah and World Agroforestry Center, 2008) 